\title{
Isotope Analysis and Radiocarbon Dating of Human Remains from El-Zuma
}

\author{
Iwona Kozieradzka-Ogunmakin
}

Isotope analysis of human remains has become a widely applied technique in the reconstruction of ancient diets (e.g. Kellner and Schoeninger 2007; Tykot 2004), human mobility and environmental changes (e.g. Loftus, Roberts, and Lee-Thorp 2016; Roberts et al. 2013; Slovak and Paytan 2011), with a growing body of research in the Nile Valley (e.g. Buzon and Bowen 2010; Buzon and Simonetti 2013; Buzon, Schrader, and Bowen 2019; Dupras and Schwarcz 2001; Iacumin et al. 1998, 2016; Schrader et al. 2019; Thompson, Chaix, and Richards 2008).

The author presents here the results of carbon $\left(\delta^{13} \mathrm{C}\right)$, oxygen $\left(\delta^{18} \mathrm{O}\right)$ and strontium $\left({ }^{87} \mathrm{Sr} /{ }^{86} \mathrm{Sr}\right)$ isotope analysis of human tooth enamel, which has been used to identify potential migrants and shed light on the diet of the ancient population of El-Zuma during the post-Meroitic/Early Makuria period (c. AD 350-60o). Tooth enamel forms during infancy and childhood, after which its chemical composition does not change (Hillson 2005). Since tooth enamel does not remodel like bone tissue, the composition of the former will reflect the diet and locality - given the local resources are consumed — of an individual during the time of enamel formation. Human remains from selected El-Zuma burials have also been used to obtain radiocarbon dates to verify the chronology of the site. For comparative reasons, stable isotope data from two nearby sites at El-Detti and El-Kurru [Fig. 7.1] have also been included. The cemetery site at El-Detti lies approximately $7.5 \mathrm{~km}$ upstream from El-Zuma. Both sites are contemporaneous and have been excavated by the PCMA team as part of the Early Makuria Research Project. The Kushite cemetery at El-Kurru is located approximately $6 \mathrm{~km}$ upstream from El-Zuma and contains royal pyramids and tumuli. The former burials were extensively excavated by George A. Reisner in 1918-1919. Artefacts and human remains recovered during his excavations at El-Kurru were brought to Boston, USA; the collection is now held at the Peabody Museum of Archaeology and Ethnology and the Museum of Fine Arts (MFA) in Boston. The samples of human dental enamel from El-Kurru were collected at the MFA.

Palaeodietary reconstruction is based on the principle that the isotopic composition of consumed food is trans-

formed by the body and preserved in human tissue, such as skin, hair, dental enamel and bone collagen (Lamb 2016; Sealy 2001). Carbon $\left(\delta^{13} \mathrm{C}\right)$ isotope analysis has been successfully applied to reconstruct dietary regimens of ancient Egyptian and Nubian populations. For example, the studies by Basha et al. (2016), Iacumin et al. (1998), Thompson et al. (2005), Thompson, Chaix, and Richards (2008), Turner et al. (2007), White (1993), and White and Schwarcz (1994) have identified seasonal fluctuations in the $C_{3} / C_{4}$ plant balance, suggesting some form of crop rotation, as well as periods of significant $\mathrm{C}_{4}$ adapted plant consumption, corresponding to low levels of the Nile and periods of social unrest. A recent study by Iacumin et al. (2016) has demonstrated changes in subsistence strategies dictated by environmental changes occurring from the pre-Mesolithic to the Meroitic period.

Carbon isotope ratios of human tooth enamel carbonate reflect the isotopic composition of dietary carbon sources. Carbon is assimilated by plants through one of three pathways $\left(\mathrm{C}_{3}, \mathrm{CAM}, \mathrm{C}_{4}\right)$, resulting in distinct $\delta^{13} \mathrm{C}$ values for each group of plants (Bender 1971; Smith and Epstein 1971). $C_{3}$ plants, which include wheat, barley, most fruits and vegetables, show values centred around $-28 \%$ o to $-26 \%$ o. $\mathrm{C}_{4}$ plants, such as sorghum and millet, demonstrate higher values centred around $-14 \%$ o to $-12 \%$. The Nubian diet was predominantly based on $\mathrm{C}_{3}$ plants; however, the consumption of $\mathrm{C}_{4}$ plants increased significantly during the post-Meroitic period ( $\mathrm{AD} 35^{\circ}-55^{\circ}$ ) (White and Schwarcz 1994). Sorghum, a $C_{4}$ plant, was likely included in the diet already during the Meroitic period (c. 300 BC-AD 35O) (Rowley-Conwy 1989), and its presence in archaeological deposits dates back to the 3rd millennium BC, based on recent evidence from Jebel Moya in southern Sudan (Brass et al. 2019).

Stable isotope of oxygen $\left(\delta^{18} \mathrm{O}\right)$ and radiogenic strontium $\left({ }^{87} \mathrm{Sr} /{ }^{86} \mathrm{Sr}\right)$ have been used successfully to investigate migration patterns in ancient Egypt and Nubia (Buzon, Simonetti, and Creaser 2007; Buzon and Simonetti 2013; Buzon and Bowen 2010; Dupras and Schwarcz 2001). A detailed review of the applicability of oxygen isotope $\left(\delta^{18} \mathrm{O} /{ }^{16} \mathrm{O}\right)$ analysis in bioarchaeology has been delivered by Pederzani and Britton (2019). Oxygen isotope has potential to reflect the individual's water intake and thus can be a proxy for location and migration. The oxy- 


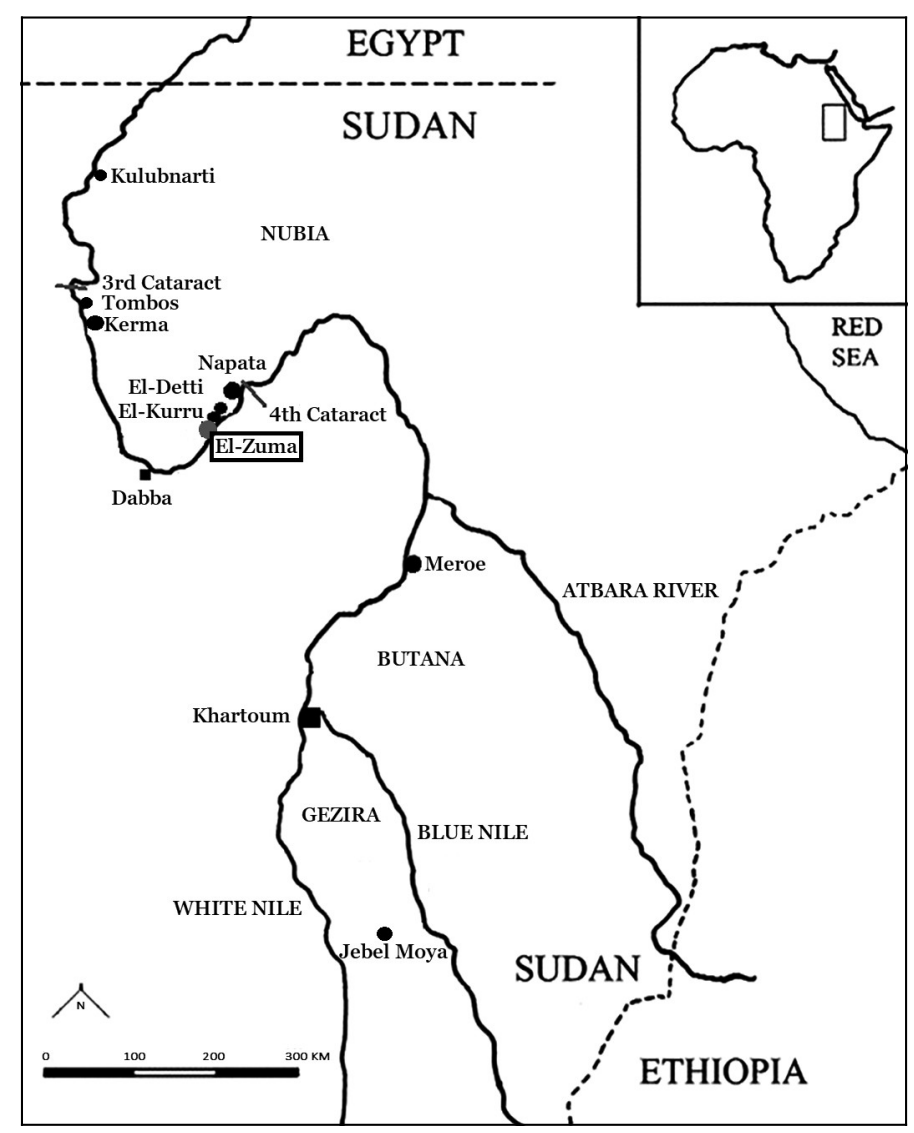

FIGURE 7.1 Location of El-Zuma and associated sites

DRAWN BY I. KOZIERADZKA-OGUNMAKIN

gen isotope $\left(\delta^{18} \mathrm{O} /{ }^{16} \mathrm{O}\right)$ ratio in enamel carbonate primarily reflects the composition of available water sources at the location where the individual lived during childhood. Dupras and Schwarcz (2001) established that there were significant differences between the oxygen isotope ratios of the teeth of individuals living in oasis communities and those of populations living in settlements in the Nile Valley. Touzeau et al. (2013) used oxygen isotope ratios in human teeth to show that there were progressive increases in the Nile water $\delta^{18} \mathrm{O}$ composition from the pre-Dynastic to the Late period, correlating with a regional climatic trend towards increasing aridity.

An overview of the applicability of radiogenic strontium isotope $\left({ }^{87} \mathrm{Sr} /{ }^{86} \mathrm{Sr}\right)$ analysis in archaeology has been presented by Slovak and Paytan (2011). Analysis of strontium isotope ratios $\left({ }^{87} \mathrm{Sr} /{ }^{86} \mathrm{Sr}\right)$ is considered a successful technique for identifying residential mobility, since strontium from the local environment is incorporated into body tissues (hydroxyapatite crystal in human tooth enamel and bone) from the consumed water and food. The ${ }^{87} \mathrm{Sr} /{ }^{86} \mathrm{Sr}$ ratios in human tissue should, therefore, reflect the ${ }^{87} \mathrm{Sr} /{ }^{86} \mathrm{Sr}$ composition of water, animals and plants consumed, in turn reflecting the ${ }^{87} \mathrm{Sr} /{ }^{86} \mathrm{Sr}$ signature of geology in a given region (Ericson 1985). Buzon et al. (Buzon, Simonetti, and Creaser 2007; Buzon and Simonetti 2013) tested the applicability of this analysis to the Nile Valley to track the movements of the ancient peoples of Egypt and Nubia, who interacted via trade, warfare, and political occupations over millennia.

\section{$2 \quad$ Materials and Methods}

\subsection{Carbon and Oxygen Isotope Analysis}

Tooth enamel samples were collected from a total of 15 individuals with preserved dentition. Where possible, canines and molars were used, except for a single case (El-Zuma T.18) where an incisor was substituted. Enamel samples for the carbon and oxygen isotope analysis were cut and prepared at the Stable Isotope Laboratory, Centre for Arctic Gas Hydrate, Environment and Climate (CAGE), the Arctic University of Norway, Tromsø. The samples 
$(n=22)$ were placed in vials and flushed with helium $(\mathrm{He})$, and five drops of water-free orthophosphoric acid $\left(\mathrm{H}_{3} \mathrm{PO}_{4}\right)$ were added manually with a syringe. Following reaction with orthophosphoric acid and chromatographic isolation of carbon dioxide $\left(\mathrm{CO}_{2}\right)$ on a Gasbench II automated preparation device, the carbon and oxygen composition of hydroxyapatite carbonate was analysed using a ThermoFisher MAT253 Isotope Ratio Mass Spectrometer (standard deviation $\leq 0.1 \% 0$ ).

Tooth enamel carbonate $\delta^{18} \mathrm{O}$ values reported relative to the VPDB standard were re-referenced to the VSMOW standard following Sharp (2007) to enable comparison with the published data:

$$
\delta^{18} \mathrm{O}_{\text {ca, vsmow }}=\left(1.03092 \times \delta^{18} \mathrm{O}_{\text {ca, vPDB }}\right)+30.92 \%
$$

\subsection{Strontium Isotope Analysis}

Archaeological human remains are susceptible to diagenetic contamination, which can alter the strontium isotope ratio of human tissue due to uptake of strontium from the burial environment. In comparison to bone tissue, tooth enamel is less susceptible to such contamination and was therefore the preferred sampling material. In order to establish the most accurate representations of biologically available ${ }^{87} \mathrm{Sr} /{ }^{86} \mathrm{Sr}$ levels, archaeological (human and faunal) and modern (botanical) samples were analysed (Price, Burton, and Bentley 2002).

All samples were prepared and analysed at the AMU Isotope Laboratory in Poznań, using published and modified methodologies (Dufour et al. 2007; Pin et al. 1994; Dopieralska 2003). Strontium $\left({ }^{87} \mathrm{Sr} /{ }^{86} \mathrm{Sr}\right.$ ) isotope ratios were measured using a Finnegan MAT-261 Thermal Ionization Mass Spectrometer. Radiogenic strontium isotope ratios were calibrated against the NBS SRM 987 standard (o.710240) and normalised to ${ }^{86} \mathrm{Sr} /{ }^{88} \mathrm{Sr}=0.1194$.

In addition to the El-Zuma samples $(n=14)$, and for comparative reasons, human enamel samples from the nearby cemetery sites at El-Detti and El-Kurru [see Fig. 7.1] were also analysed. To establish the local strontium isotope range, samples of archaeological faunal remains from funerary contexts at El-Zuma $(n=3)$ and El-Detti $(n=3)$, as well as modern botanical samples $(n=5)$ were analysed. The former included the following taxa: sheep/goat (Ovis/Capra) (El-Zuma, $n=1$; El-Detti, $n=1$ ), cattle (Bos) (El-Zuma, $n=2$; El-Detti, $n=1$ ), and $\operatorname{dog}$ (Canis) (El-Detti, $n=1)$. Botanical samples of the local shrubs were collected in the vicinity of the cemetery at El-Zuma, away from agricultural fields and water sources. For comparative purposes, a single botanical sample was also collected from a location a few kilometres north of the cemetery at ElKurru, known as the Stone Forest.

\section{Results and Discussion}

\subsection{Carbon and Oxygen Isotopic Results}

Table 7.1 and Fig. 7.2 provide the results of the carbon and oxygen stable isotope analysis of human tooth enamel from El-Zuma. The mean $\delta^{13} \mathrm{C}$ value is $-5.06 \%$ with values ranging from $-8.15 \%$ to $-2.83 \%$. These are very high values in comparison to the New Kingdom/Third Intermediate Period site at Tombos $($ mean $=-11.8 \%$ o $[-13.4 \%$ o to $-7.2 \% 0]$; Buzon and Bowen 2010) but similar to those from the Meroitic site at Al-Khiday ${ }^{1}$ (mean $=-7.0 \%$ o $[-9.0 \%$ to $-4.2 \%$ ]), where the mean contribution of $\mathrm{C}_{4}$ plants was approximately $30 \%$ (Iacumin et al. 2016). The $\mathrm{C}_{4}$ plant contribution in the diet could be due to the direct consumption of $\mathrm{C}_{4}$ plants, such as cereals and tubers, or to the consumption of meat from domesticated herbivores feeding on $\mathrm{C}_{4}$ plants and thus providing ${ }^{13} \mathrm{C}$-enriched meat to humans (Iacumin et al. 2016). The results would, therefore, be consistent with the previous isotopic research on the diet of the Nubian population, which has indicated a $\mathrm{C}_{3}$-plant dominated $\operatorname{diet}\left(\% \mathrm{C}_{4}=10-25\right)$, with an increase in consumption of $\mathrm{C}_{4}$ plants during the postMeroitic period (White and Schwarcz 1994).

The large range of values may indicate the presence of non-local individuals. When only values obtained from the molar (post-weaning) teeth are considered, the lowest $\delta^{13} \mathrm{C}$ value was obtained for the individual from T.27, further in the text identified as an outlier and likely nonlocal individual based on the oxygen value and ${ }^{87} \mathrm{Sr} /{ }^{86} \mathrm{Sr}$ ratio. However, despite the second lowest $\delta^{13} \mathrm{C}$ value in the tooth enamel from T.16, this individual has been considered local based on the ${ }^{87} \mathrm{Sr} /{ }^{86} \mathrm{Sr}$ ratio. A similar carbon value was recorded for T.9; however, there is no strontium value for this individual to determine whether they were likely of local or non-local origin. When $\delta^{13} \mathrm{C}$ values from pre- and post-weaning teeth are compared (canines versus molars; see Table 7.1), the latter are enriched by $\sim 2 \%$ o in three of the cases (T.9, T.15, T.17); however, in two further cases (T.16 and T.27) the $\delta^{13} \mathrm{C}$ values for molars are slightly depleted. ${ }^{13} \mathrm{C}$-enrichment in pre-weaning teeth has been noted in a Roman-era population at Dakhleh Oasis in Egypt and linked to the weaning process and early introduction of ${ }^{13} \mathrm{C}$-enriched supplementary foods (Dupras, Schwarcz, and Fairgrieve 2001). As observed elsewhere and in three cases at El-Zuma, breastfeeding infants would usually be depleted in ${ }^{13} \mathrm{C}$ due to the consumption of lipids from breast milk (Wright and

1 Al-Khiday is an area located south of Omdurman with nine archaeological sites identified so far. 


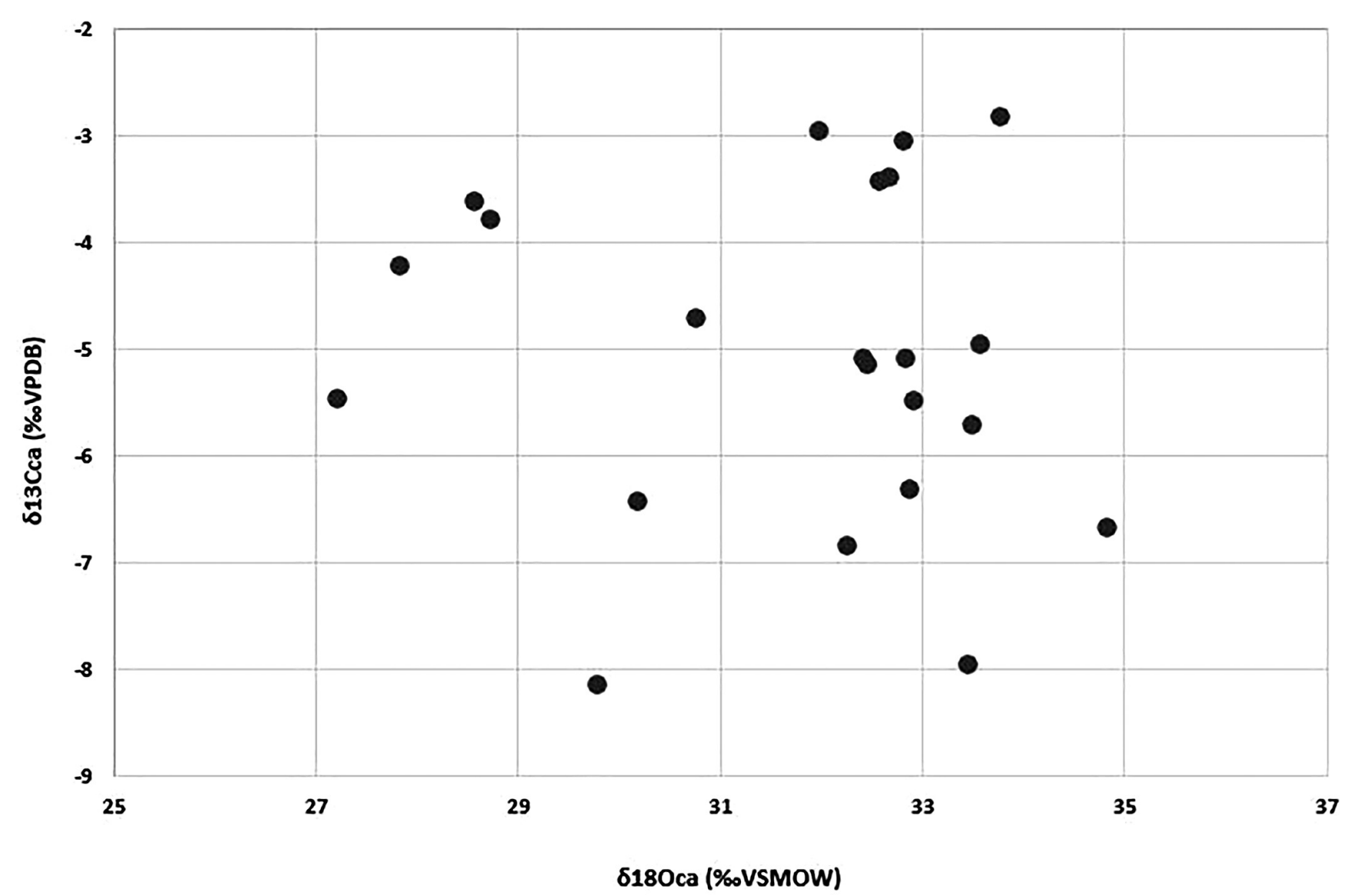

FIGURE 7.2 Distribution of $\delta^{13} \mathrm{C}_{\text {ca }}$ and $\delta^{18} \mathrm{O}_{\text {ca }}$ values for El-Zuma individuals PRODUCED BY I. KOZIERADZKA-OGUNMAKIN

Schwarcz 1998, 1999). The observed differences within the El-Zuma population could suggest differences in weaning practices and likely non-local origin of the individuals (e.g. T.27).

The mean $\delta^{18} \mathrm{O}_{\text {ca }}$ value for human tooth enamel samples from El-Zuma is $31.7 \%$, with values ranging from $27.21 \%$ o to $34.83 \%$. The range of values measured for tooth enamel carbonate in the El-Zuma individuals is large $(\sim 7.6 \%$ ) but close to those observed at other Nubian sites [Table 7.2], such as Wadi Halfa ( $6 \%$; White, Longstaffe, and Law 2004), Tombos ( 6.1\%o; Buzon and Bowen 2010) and AlKhiday ( $\sim \%$; Iacumin et al. 2016). Like these sites, the large range of values is likely indicative of the presence of non-local individuals. It should be pointed out, however, that a variety of water sources (the Nile and ground water) and treatment of water (for example, boiling, irrigation and storage) could also account for a large range of values.

\subsection{Strontium Isotopic Results}

The ${ }^{87} \mathrm{Sr} /{ }^{86} \mathrm{Sr}$ ratios for the individuals $(n=14)$ buried at El-Zuma range from 0.706899 to 0.708725 , as presented in Table 7.1. However, the majority $(n=12)$ of the values fall within a smaller range, from 0.707004 to 0.707392 , which also covers the values for the individuals from the nearby El-Kurru and some from El-Detti [Table 7.3 and Fig. 7.3]. Using the ${ }^{87} \mathrm{Sr} /{ }^{86} \mathrm{Sr}$ ratios of the archaeological faunal remains and modern botanical samples from ElZuma and El-Detti [see Table 7.3], the local strontium range of $0.706984^{-0.707522}$ was determined by the mean of ratios $(0.707253) \pm$ standard deviation $(\mathrm{SD}=0.000269)$.

The strontium ratios of two El-Zuma individuals fall outside the local range (T.14: 0.706899 and T.27: 0.708725). In particular, the individual from T.27 has a much higher value in comparison to all archaeological and modern botanical samples from the local area. As teeth do not remodel, their isotopic ratios remain constant from the time of their formation during childhood. Since the two values are different from the local range where the burial took place, this signals the individuals' non-locality. It is 
TABLE 7.1 Carbon, oxygen and strontium isotope values for individuals from El-Zuma

\begin{tabular}{|c|c|c|c|c|c|c|}
\hline Sample ID & Sex & Tooth & $\delta^{13} C_{c a} \% o V P D B$ & $\delta^{18} O_{\text {ca }} \% o V P D B$ & $\delta^{18} O_{\text {ca }} \% o v s M O W$ & ${ }^{87} \mathrm{Sr} /{ }^{86} \mathrm{Sr}$ \\
\hline El-Zuma T.9 & M?? & $\mathrm{C}$ & -8.15 & -1.09 & $29 \cdot 79$ & - \\
\hline El-Zuma T.9 & M?? & $\mathrm{M}_{3}$ & -6.31 & 1.89 & $3^{2.87}$ & - \\
\hline El-Zuma T.1o & $\mathrm{M}$ & M1 & -3.80 & -2.12 & 28.74 & 0.707392 \\
\hline El-Zuma T.11 & $?$ & M1 & - & - & - & 0.707129 \\
\hline El-Zuma T.11 & $?$ & $\mathrm{M} 2$ & -3.41 & 1.70 & $3^{2.68}$ & - \\
\hline El-Zuma T.13 & $\mathrm{M} ?$ & $\mathrm{M}_{1}$ & $-5 \cdot 47$ & $-3.6 o$ & 27.21 & 0.707257 \\
\hline El-Zuma T.14 & $\mathrm{F} ?$ & M1 & -5.15 & 1.49 & 32.45 & 0.706899 \\
\hline El-Zuma T.14 & $\mathrm{F} ?$ & $\mathrm{M}_{3}$ & -5.11 & 1.46 & 32.42 & - \\
\hline El-Zuma T.15 & $\mathrm{F} ? ?$ & $\mathrm{C}$ & -4.23 & -2.98 & 27.85 & - \\
\hline El-Zuma T.15 & $\mathrm{F} ?$ & $\mathrm{M}_{1}$ & - & - & - & 0.707182 \\
\hline El-Zuma T.15 & $\mathrm{F} ?$ & $\mathrm{M}_{3}$ & -2.96 & 1.02 & 31.97 & - \\
\hline El-Zuma T.16 & M?? & $\mathrm{C}$ & -6.44 & -0.70 & 30.20 & - \\
\hline El-Zuma T.16 & M?? & $\mathrm{M}_{1}$ & - & - & - & 0.707004 \\
\hline El-Zuma T.16 & M?? & $\mathrm{M}_{3}$ & -6.85 & 1.29 & $3^{2.25}$ & - \\
\hline El-Zuma T.17 & $\mathrm{M}$ & $\mathrm{C}$ & -4.96 & $2.5^{8}$ & $33 \cdot 5^{8}$ & - \\
\hline El-Zuma T.17 & $\mathrm{M}$ & M1 & - & - & - & 0.707271 \\
\hline El-Zuma T.17 & $\mathrm{M}$ & $\mathrm{M} 2$ & -2.83 & 2.76 & $33 \cdot 77$ & - \\
\hline El-Zuma T.1 8 & $\mathrm{~F} ?$ & I1 & -3.62 & -2.28 & 28.57 & 0.707226 \\
\hline El-Zuma T.2O & M?? & $\mathrm{C}$ & -5.48 & 1.92 & 32.90 & - \\
\hline El-Zuma T.2o & M?? & M1 & - & - & - & 0.707392 \\
\hline El-Zuma T.21 & $\mathrm{M}$ & $\mathrm{M}_{1}$ & - & - & - & 0.707187 \\
\hline El-Zuma T.21 & $\mathrm{M}$ & $\mathrm{M} 2$ & -3.05 & 1.83 & 32.81 & - \\
\hline El-Zuma T.22 & $\mathrm{M}$ & $\mathrm{M} 2$ & $-5 \cdot 71$ & 2.50 & $33 \cdot 5^{\circ}$ & 0.707268 \\
\hline El-Zuma T.24 & $\mathrm{F} ?$ & M1 & -5.08 & 1.85 & 32.83 & 0.707010 \\
\hline El-Zuma T.25 & $\mathrm{F}$ & $\mathrm{M}_{1}$ & $-4 \cdot 73$ & -0.14 & 30.77 & 0.707096 \\
\hline El-Zuma T.25 & $\mathrm{F}$ & $\mathrm{M}_{3}$ & -3.43 & 1.61 & $3^{2.5} 5^{8}$ & - \\
\hline El-Zuma T.27 & $\mathrm{M}$ & $\mathrm{C}$ & -6.68 & $3 \cdot 79$ & 34.83 & - \\
\hline El-Zuma T.27 & $\mathrm{M}$ & M1 & - & - & - & 0.708725 \\
\hline El-Zuma T.27 & $\mathrm{M}$ & $\mathrm{M}_{3}$ & $-7 \cdot 96$ & 2.47 & 33.47 & - \\
\hline
\end{tabular}

*Sex estimates were recorded as "M" for male, "F" for female, and "?" for undetermined sex; question marks next to sex estimates (e.g. "M?” or “M??”-probable male) reflect degree of uncertainty (see Chapter 6 of this volume). Sampled teeth included: central incisor (I1), canine (C), molars (M1-3)

PRODUCED BY I. KOZIERADZKA-OGUNMAKIN

impossible to indicate where the two individuals could have likely originated from due to the currently limited research on biological and geological ${ }^{87} \mathrm{Sr} /{ }^{86} \mathrm{Sr}$ ratio variability in the Nile Valley. ${ }^{2}$ Interestingly, the two individuals

2 The geology of the area stretching between the Third and Fourth Cataracts (the Great Bend of the Nile) is represented by the Cretaceous Nubian sandstones formation made of continental clastic sediments which include sandstones, siltstones, mudstones and conglomerates (non-outcrop to the right of the Nile and predominantly outcrop in the area to the left of the Nile in downstream direction). Recent alluvial deposits run along the Nile ("Geological Map of the Sudan" 1981; Panagos et al. 2011).
(T.14 and T.27) also demonstrate the highest $\delta^{18} \mathrm{O}_{\text {ca }}$ values in the local range, which could be indicative of their non-local origin and support the strontium data interpretation. High $\delta^{18} \mathrm{O}_{\text {ca }}$ values, however, have also been recorded for the individuals who appear to be local based on their strontium ratios and local range. It is, therefore, apparent that the individuals identified as non-local using the oxygen and strontium isotope analyses do not necessarily correspond. Similar observations have been made at Kulubnarti and Tombos (Buzon and Bowen 2010). This discrepancy in identifying non-local individuals using these two methods could be due to different principles, 
TABLE 7.2 Comparison of $\delta^{18} \mathrm{O}_{\text {ca }}$ from the Nile Valley sites

\begin{tabular}{|c|c|c|c|c|}
\hline Site & Time period & $\begin{array}{l}\text { Mean } \delta^{18} \mathrm{O}_{\text {ca }} \\
\text { \%ovsmow (range) }\end{array}$ & Sample & Reference \\
\hline Mendes & Graeco-Roman (332 BC-AD 395) & $31.1(29.8-31.5)$ & Enamel carbonate & Prowse et al. 2007 \\
\hline Asyut & $\begin{array}{l}\text { First Intermediate Period }\left(215^{\circ}-\right. \\
2025 \mathrm{BC})\end{array}$ & $31.6\left(30.2-3^{2.1}\right)$ & Bone carbonate & Iacumin et al. 1996 \\
\hline Gebelein & Predynastic (35оо-26оовс) & $31.6(31.0-32.3)$ & Bone carbonate & Iacumin et al. 1996 \\
\hline Gebelein & $\begin{array}{l}\text { First Intermediate Period }\left(215^{\circ}-\right. \\
2025 \mathrm{BC})\end{array}$ & $31.4(30.6-31.9)$ & Bone carbonate & Iacumin et al. 1996 \\
\hline *Kellis, Dakhleh Oasis & Roman-Byzantine (AD 50-350) & $28.2(24 \cdot 3-31.6)$ & Bone carbonate & Dupras and Schwarcz 2001 \\
\hline Wadi Halfa & $\begin{array}{l}\text { X-Group (AD 350-550) and Chris- } \\
\operatorname{tian}(\mathrm{AD} 5 \mathrm{OO}-1400)\end{array}$ & $33.0(29.8-35 \cdot 7)$ & $\begin{array}{l}\text { Bone and enamel } \\
\text { carbonate }\end{array}$ & $\begin{array}{l}\text { White, Longstaffe, and Law } \\
2004\end{array}$ \\
\hline Kulubnarti & Christian (AD 50o-80o) & $33.7(32.1-36.00)$ & Bone carbonate & Turner et al. 2007 \\
\hline Tombos & $\begin{array}{l}\text { New Kingdom and Third Intermedi- } \\
\text { ate Period }(1400-105 \text { о вС })\end{array}$ & $31.4(29.2-35 \cdot 3)$ & Enamel carbonate & Buzon and Bowen 2010 \\
\hline El-Zuma & $\begin{array}{l}\text { Late to post-Meroitic/Early Makuria } \\
\text { (AD 9o-6oo) }\end{array}$ & $31.7(27.2-34.8)$ & Enamel carbonate & \\
\hline Al-Khiday & Meroitic (3оо в C-AD 350) & $33.6(29.7-35 \cdot 7)$ & Bone carbonate & Iacumin et al. 2016 \\
\hline
\end{tabular}

* Oasis site outside the Nile Valley

PRODUCED BY I. KOZIERADZKA-OGUNMAKIN

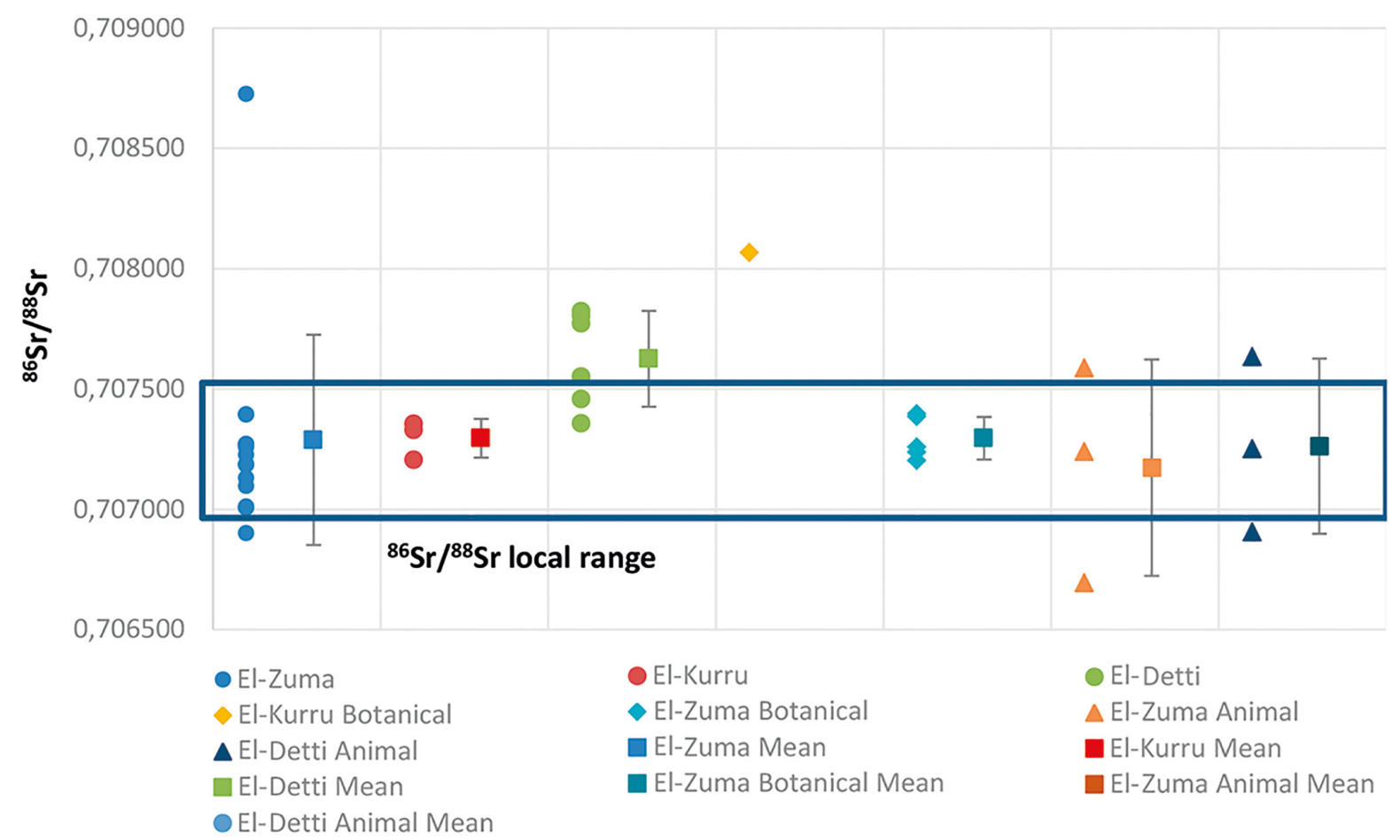

FIGURE 7.3 Distribution of ${ }^{87} \mathrm{Sr} /{ }^{86} \mathrm{Sr}$ values for human, faunal and botanical samples PRODUCED BY I. KOZIERADZKA-OGUNMAKIN 
TABLE 7.3 Strontium values for human remains from El-Detti and El-Kurru and faunal and botanical remains from El-Zuma, El-Detti and El-Kurru

\begin{tabular}{|c|c|c|c|c|}
\hline Sample ID & Lab iD no. & Sample & ${ }^{87} \mathrm{Sr} /{ }^{86} \mathrm{Sr}$ & Internal precision \\
\hline & & Human (archaeological tooth enamel) & & \\
\hline El-Detti T.2 & SM-047 & M1 & 0.707205 & \pm 0.000010 \\
\hline El-Detti T.5 & SM-048 & M1 & 0.707354 & \pm 0.000010 \\
\hline El-Detti T.7 & SM-049 & M1 & $0.70755^{\circ}$ & \pm 0.000010 \\
\hline El-Detti T.3 & SM-076 & $\mathrm{M}_{3}$ & 0.707329 & \pm 0.000009 \\
\hline El-Detti T.6 & SM-O78 & $\mathrm{P}$ & $0.70735^{6}$ & \pm 0.000009 \\
\hline El-Detti T.7, Lower M1 & SM-O79 & M1 & 0.707456 & \pm 0.000009 \\
\hline El-Kurru, Eg. Inv. $46 \circ 6$ & $\mathrm{SM}-\mathrm{O} 38$ & M1 & 0.707803 & \pm 0.000009 \\
\hline El-Kurru, 22-1-534r & SM-039 & I1 & 0.707822 & \pm 0.000014 \\
\hline \multirow[t]{2}{*}{ El-Kurru, 46o8, M2 } & SM-068 & $\mathrm{M} 2$ & 0.707772 & \pm 0.000009 \\
\hline & & $\begin{array}{l}\text { Animal (archaeological bone) } \\
\text { cattle (Bos) }\end{array}$ & & \\
\hline $\begin{array}{l}\text { El-Zuma 1.4: Z4/187 } \\
\text { El-Zuma T.14: Z14/6 }\end{array}$ & $\begin{array}{l}\mathrm{SM}-081 \\
\mathrm{SM}-082\end{array}$ & $\begin{array}{l}\text { cattle (Bos) } \\
\text { sheep/goat (Ovis/Capra) }\end{array}$ & $\begin{array}{l}0.707239 \\
0.707586\end{array}$ & $\begin{array}{l} \pm 0.000010 \\
\pm 0.000010\end{array}$ \\
\hline El-Zuma T.24: Zs-21,Z/B/24/3 & $\mathrm{SM}-083$ & cattle $(B o s)$ & 0.706694 & \pm 0.000010 \\
\hline El-Detti T.1: DS-1 & SM-084 & cattle (Bos) & 0.707633 & \pm 0.000010 \\
\hline El-Detti T.4 & SM-085 & sheep (Ovis) & $0.70725^{\circ}$ & \pm 0.000010 \\
\hline \multirow[t]{2}{*}{ El-Detti T.4 } & SM-086 & $\operatorname{dog}$ (Canis) & 0.706906 & \pm 0.000010 \\
\hline & & Botanical (modern) & & \\
\hline El-Kurru (Stone Forest) & sM-o6o & shrubs & 0.708067 & \pm 0.000009 \\
\hline El-Zuma $\mathrm{P}_{1}$ & SM-062 & shrubs & 0.707384 & \pm 0.000010 \\
\hline El-Zuma $\mathrm{P}_{2}$ & sM-o63 & shrubs & 0.707396 & \pm 0.000010 \\
\hline El-Zuma $\mathrm{P}_{3}$ & sM-064 & shrubs & 0.707203 & \pm 0.000010 \\
\hline El-Zuma $\mathrm{P}_{4}$ & sM-065 & shrubs & 0.707238 & \pm 0.000010 \\
\hline El-Zuma $\mathrm{P}_{5}$ & sM-o66 & shrubs & $0.70725^{8}$ & \pm 0.000010 \\
\hline
\end{tabular}

* Sampled human teeth from El-Detti included: central incisor (I1), premolar (P), molars (M1-3). Shrub species (small size) were not identified.

PRODUCED BY I. KOZIERADZKA-OGUNMAKIN

and their applicability in the Nile Valley warrants further investigation.

\section{$4 \quad$ Radiocarbon Dating}

Based on the funerary evidence and associated artefacts, the cemetery site at El-Zuma was in use during the post-Meroitic/Early Makuria period (c. AD 350-60o). To verify the archaeological dating of the site, samples of human bone and teeth from selected funerary contexts (El-Zuma T.14, T.18, T.21 and T.24) were submitted for radiocarbon dating. Of these, one sample (El-Zuma T.14) was disqualified due to insufficient amount of collagen. The analysis was conducted at the Poznań Radiocarbon Laboratory and Gliwice Radiocarbon Laboratory (GADAM Centre), Institute of Physics, Silesian University of Techno- logy. Radiocarbon dates were calibrated using the OxCal 4.3 program (Bronk Ramsey 2009, 2017; Bronk Ramsey and Lee 2013) and IntCal13 atmospheric calibration curve (Reimer et al. 2013).

The ${ }^{14} \mathrm{C}$ dates [Table 7.4] obtained for the selected samples confirm that the cemetery was in use during the post-Meroitic period (El-Zuma T.21 and T.24) and as early as the Late Meroitic period (c. AD 9O-350) based on the AMS date obtained for the human remains recovered from T.18. This finding puts the cemetery in a new light; additional radiocarbon dates from the remaining funerary contexts should assist with establishing the time span of the cemetery's use and investigating the funerary practices of the local population during that period. 
TABLE 7.4 Radiocarbon dates for selected funerary contexts at El-Zuma

\begin{tabular}{llllll}
\hline Sample ID & Lab No. & ${ }^{14}$ C yr bp & Calibrated BC (94.5\%) & Material & Comments \\
\hline El-Zuma T.14 & Poz-O & - & - & tooth & failed \\
El-Zuma T.18 & Poz-101750 & $1830 \pm 30$ & AD 86-311 & bone & \\
El-Zuma T.21 & Poz-101746 & $1615 \pm 30$ & AD 387-538 & bone & \\
El-Zuma T.24 & GdA-5761 & $1645 \pm 35$ & AD 264-535 & tooth & enamel used \\
\hline
\end{tabular}

PRODUCED BY I. KOZIERADZKA-OGUNMAKIN

\section{Conclusions}

The application of isotope analysis to the study of human remains recovered from the funerary contexts at El-Zuma presented both a challenge and an opportunity. The state of preservation of the skeletal remains, generally characterized by extensive incompleteness, fragmentation and bone degradation, presented numerous limitations for osteological assessment and the subsequent reconstruction of the individuals' biological profiles (see Chapter 6 of this volume). With highly degraded bone tissue, the study focused on isotope analysis of dental enamel-the hardest and highly mineralised tissue in human body-to address the questions pertaining to diet and locality of the individuals buried in the tumuli at El-Zuma.

The analysis of the ratio of carbon $\left(\delta^{13} \mathrm{C}\right)$, oxygen $\left(\delta^{18} \mathrm{O}\right)$ and strontium $\left({ }^{87} \mathrm{Sr} /{ }^{86} \mathrm{Sr}\right)$ isotopes in dental enamel allowed to identify potential migrants and shed light on the diet of the ancient population of El-Zuma during the post-Meroitic/Early Makuria period (c. AD 350-6oo). The results suggest that the local population had a $\mathrm{C}_{3}$ plant dominated diet with the contribution of $\mathrm{C}_{4}$ plants equating to approximately $30 \%$. This finding is consistent with the previous isotopic research on the diet of the Nubian population, which has indicated a $\mathrm{C}_{3}$-plant dominated diet $\left(\% \mathrm{C}_{4}=10-25\right)$, with an increase in consumption of $\mathrm{C}_{4}$ plants during the post-Meroitic period (White and Schwarcz 1994).

The large range of isotopic values and the presence of outliers may be indicative of their non-local origin (e.g. T.14 and T.27). However, the study showed that the individuals identified as non-local using the oxygen and strontium isotope analyses do not necessarily correspond; an observation also made at other Nubian sites (Buzon and Bowen 2010). This discrepancy in identifying nonlocal individuals using these two methods could be due to different principles, and their applicability in the Nile Valley warrants further investigation. In particular, more research is needed on regional isotopic variability to enable meaningful data interpretation and conclusions.
This study presents a small but important contribution to the growing body of isotopic research on the subsistence and pattern of human habitation and migration in the Nile Valley, particularly in relation to environmental and major socio-political changes, such as the collapse of the Meroitic kingdom and the formation of independent Christian kingdoms. As this and many other similar studies have demonstrated, isotope analysis of human, but also animal remains offers unparalleled data that can greatly benefit archaeological research in Nubia and beyond. 